\title{
Learning Communication Strategy at Colleges During the Covid-19 Pandemic and the New Normal Phase
}

\author{
Ratri Candrasari ${ }^{1 *}$, Harinawati ${ }^{1}$, Risna Dewi ${ }^{2}$, Kurniawati $^{3}$, Dini Rizki ${ }^{4}$, Richa \\ Meliza $^{5}$, Cut Rizka Al Usrah ${ }^{4}$, Teuku Kemal Fasya ${ }^{5}$ \\ ${ }^{I}$ Communication Science Department, Social and Political Science Faculty, Universitas Malikussaleh, Aceh, \\ Indonesia \\ ${ }^{2}$ Public Administration Department, Social and Political Science Faculty, Universitas Malikussaleh, Aceh, Indonesia \\ ${ }^{3}$ Informatics Department, Engineering Faculty, Universitas Malikussaleh, Aceh, Indonesia \\ ${ }^{4}$ Sociology Department, Social and Political Science Faculty, Universitas Malikussaleh, Aceh, Indonesia \\ ${ }^{5}$ Anthropology Department, Social and Political Science Faculty, Universitas Malikussaleh, Aceh, Indonesia \\ ${ }^{*}$ Corresponding author.Email: ratri@unimal.ac.id
}

\begin{abstract}
This study aims to formulate a learning communication model that is able to replace or modify the type of learning communication from the face-to-face system to blended learning during the Covid-19 pandemic and in the new normal period. This study focuses on learning communication in tertiary institutions on the grounds that students are expected to be independent in learning so that they no longer expect parental guidance in taking online classes, as happened at the primary and secondary education levels. With the consideration of the two things above, namely changes in learning communication with e-learning and the level of student independence, it is necessary to have a learning communication strategy in higher education to welcome the formation of a digital society. In this study, the tertiary institutions that were the object of research were three state universities in the North Aceh region and Lhokseumawe city, namely Malikussaleh University, Lhokseumawe State Polytechnic, and UIN Malikussaleh. The choice of the three universities refers to an effort to avoid long trips during the pandemic, because in addition to interviews using interactive virtual media remotely, in obtaining some information, direct observation must be used. The research was conducted using mixed approach -quantitative and qualitative-by involving respondents and informants from three main elements of the object of education, namely lecturers, students, and the community. In addition to interviews, Focus Group Discussion (FGD) was also conducted using the zoom application, by presenting an expert resource person who is active in Online learning training, namely Prof. Ujang Sumarna from the Bogor Agricultural Institute. The outcome in this study is the existence of a learning communication strategy in tertiary institutions in a region with regional criteria that are relatively far from the nation's capital with relatively lacking information and communication technology facilities. The outcomes are a model of blended learning as an alternative and a model of e-learning Maturity Model (eMM) as a strategy to prepare all elements of colleges to face the changes in education in this disruptive era.
\end{abstract}

Keywords: Learning communication strategy, e-learning, covid-19 pandemic, new normal

\section{INTRODUCTION}

The Covid-19 pandemic that reached Indonesia since mid-March 2020, has changed all lines of life, including in the world of education. Various schools, campuses, and educational institutions implement online learning policies as an alternative to maintaining the continuity of the teaching and learning process. During this pandemic, all elements were forced to take part in the learning process, not only teachers and students, but also parents, especially in primary and secondary education where students still have a level of independent learning which still depends on parental guidance. 
The online policy was taken following calls for Work from Home (WFH) and the \#dirumahaja Movement initiated by the central government. Since the implementation of WFH, there has been a significant impact not only on the business world, but also on the world of education. This change certainly caused reactions from many parties. Various mass media and social media inform various problems faced by the community, especially parents of students. Complaints start from technical problems such as the absence of communication tools, difficult to find networks, economic problems caused by the lack of funds to buy credit and internet quota, to psychological complaints faced by students and parents when implementing online learning.

In terms of teachers and lecturers who act as controllers of online learning, they also face various problems that also arise in the online learning process. The effectiveness of this learning is greatly influenced by the expertise of teachers and lecturers in managing online classes which of course have different characteristics from face-to-face learning. At the tertiary level, students are expected to be able to learn independently by utilizing resources and technology.

Crisis management according to [1] that in every crisis situation there are 4 crisis phases, namely, the prodromal phase, acute, chronic, and resolution. The prodromal phase is the warning phase, which is the phase where early signs of a crisis appear, in this case the Covid-19 pandemic. Furthermore, the acute stage is the starting point for the emergence of a pandemic in our country, and the chronic stage is the stage where all are aware of a pandemic and begin to learn how to overcome the crisis. The next stage of resolution is the stage of recovery. Back when the pandemic graph has sloped sharply.

Currently, the Covid-19 pandemic in our country is entering an acute and chronic stage. At this acute and chronic level, in the world of education there is a change in the learning process, learning communication is carried out by distance learning or online. This revolutionary change certainly devastates the state of the learning system with its technical and financial unpreparedness, not to mention mental readiness or the habit of digital society.

The Indonesian Minister of Education and Culture, Nadiem Makarim, has issued several policies to regulate learning activities during the Covid-19 pandemic. This was issued through Circular Number 4 of 2020, namely regarding the Implementation of Education Policies in the Emergency of the Spread of Coronavirus Disease (Covid-19), dated March 4, 2020. To be precise there are good policies presented but the most basic is the learning procedure with the learning policy in House.
Actually, the government has carried out community literacy by means of distance learning through various programs, long before the Covid-19 pandemic. Starting with the open university program in 1984 until now. Then in 2014, the government launched the Integrated Indonesian Online Learning (PDITT) program which later changed its name to the Online Learning System (SPADA), with the aim of equitable access to quality learning in universities.

The government is currently also preparing activities towards the new normal resolution phase. In the resolution or new normal phase, learning in tertiary institutions will also change the learning system that refers to health protocols in the new normal era. In this phase the expert suggested the application of Blended Learning which combines online and face-to-face learning.

This research will involve three state universities in the district of North Aceh and Lhokseumawe city, namely Malikussaleh University, Lhokseumawe State Polytechnic, and UIN Malikussaleh. The three universities in preliminary research through observation and light interviews concluded that they had made various learning efforts following the Covid-19 pandemic protocol, including online learning. In its implementation, the three universities experienced relatively uniform obstacles. Higher education readiness with existing application facilities such as campus elearning is very helpful, although in its implementation it is necessary to improve user capacity, and some menus are not yet perfect. Several lecturers took the initiative to use several applications that were widely circulated in general but not yet and some were never touched on the grounds that they did not need them.

This study will describe and analyse the learning communication strategy that is being applied and which will be applied in the new normal period. In addition, the research results will be followed up with analysis and evaluation of learning communication with an elearning expert from IPB Bogor, Prof. Ujang Sumarna through Focus Group Discussion (FGD) using a virtual zoom application.

Based on several phenomena and the desire to analyse the communication strategy for implementing learning for future implementation, not only during the Covid-19 pandemic, the researcher took the title "Learning Communication Strategy during the Covid-19 Pandemic and Preparation for New Normal (Study at State Universities in North Aceh district) and the city of Lhokseumawe). " 


\section{LITERATURE REVIEW}

In carrying out the THIS RESEARCH, it is necessary to use studies and theoretical or conceptual foundations, as follows:

\subsection{Learning Communication}

Communication science is a branch of science that covers almost all aspects of life and various fields of community life, one of which is the field of learning or education. The definition of learning communication is the process of delivering ideas from one person to another in order to achieve success in sending messages to the target audience effectively and efficiently.

In learning activities, interpersonal communication (Interpersonal Communication) is a must, so that there is a harmonious relationship between the teacher and the learning participants. The effectiveness of communication in this learning activity really depends on both parties. However, because the teacher holds the responsibility of the class, the responsibility for healthy and effective communication in the classroom lies with the teacher. The success of the teacher in carrying out this responsibility is greatly influenced by their skills in carrying out this communication.

\subsubsection{Function of Communication}

Communication science is a branch of science that covers almost all aspects of life and various fields of community life, one of which is the field of learning or education. The definition of learning communication is the process of conveying ideas from one person to another so that according to Judy C. Pearson and Paul E Nelson (2011), communication has two general functions. First, for one's own survival which includes: physical safety, increasing personal awareness, presenting oneself to others and achieving personal ambition. Second, for the survival of the community, precisely to improve social relations and develop the existence of a society.

Meanwhile, according to [2] Communication has 4 functions, namely:

a) Social Communication Function

People who never communicate with humans will disappear, because they cannot organize themselves in a social environment. Without being involved in communication, a person will not know how to be a civilized human. The conclusion is that people communicate to show themselves to exist.

b) Expressive Functions

Expressive communication is often used to convey human feelings. Most of this communication is delivered in non-verbal form. Expressions of affection, anger, or shame can be conveyed in words, but they are more effective when communicated with body language.

c) Ritual Communication Function

This communication function is related to expressive communication, but in the form of delivery it is done collectively. Those involved in ritual communication are seen as trying to affirm and also as an individual's commitment to their social life.

d) Instrumental Communication Function

The function of instrumental communication is to explain, teach, inform, encourage, change attitudes and beliefs, change behavior or drive action, and also to entertain. As an instrument, communication is not only used by humans to create and build relationships, but also to destroy these relationships.

\subsubsection{Principles of Learning Communication}

There are 4 communication principles that can also be applied to learning communication, Gordon also stated that communication can be applied using the REACH concept (Respect, Empathy, Audible, Clarity, and Humble). Here are 4 principles of communication:

a) Respect: the first principle in developing effective communication is mutual respect.

b) Emphaty: one of the human abilities to place oneself in situations or conditions faced by others.

c) Audible: can be heard or understood well.

d) Clarity: the clarity principle is the clarity of the message content so as not to cause multiple interpretations.

e) Humble: building effective communication is with a humble attitude.

According to [3], learning communication is said to be effective if there is a two-way flow of information between educators and students and this information is both responded to in accordance with the expectations of the two actors of communication, at least 5 aspects must be met:

a) Clarity: communication must use language that is clearly packaged so that it is easily accepted and understood by the communicant.

b) Accuracy: use of correct language and correctness of correct information.

c) Context: the language and information conveyed must be appropriate to the circumstances and environment.

d) Flow: the language and information to be presented must be arranged in a clear flow or systematic manner, so that the party receiving the information is responsiveej) Culture: This aspect concerns not only language and information, but also manners and ethics.

\subsection{Covid-19 Pandemic}

The Covid-19 pandemic is a new virus that causes disease in humans as well as animals. This virus causes 
respiratory tract infections such as colds and coughs. This virus has been found in humans since December 2019, which was originally named severe acute respiratory syndrome coronavirus 2 (SARS-COV2). Based on data from the World Health Organization (WHO), the spread of the Covid-19 virus is expanding throughout the world, including Indonesia. On January 30, 2020, WHO designated Covid-19 as a Public Health Emenrgency of International Concern (PHEIC) or a Public Health Emergency that Concerned the World (KKMMD). On 12 February 2020, WHO officially designated this disease as the coronavirus disease (Covid-19).

Currently, Indonesia is entering the Covid-19 pandemic emergency and according to covid.go.id data, Indonesia has a high positive corona number. The President made a policy to carry out social distancing to break the chain of spreading Covid-19. The next policy is Large-Scale Social Restrictions (PSBB) based on PP. 21 of 2020 article 1 PSBB.

Activities that are limited during the Covid-19 pandemic are the temporary cessation of several mass activities such as religious activities, activities in public places, socio-cultural activities, cessation of public transportation, and also the cessation of face-to-face learning activities at schools/campuses.

\subsection{New Normal}

The definition of new normal in Indonesia is a scenario to accelerate the handling of COVID-19 in the health and socio-economic aspects. The Indonesian government has announced plans to implement the new normal scenario taking into account epidemiological studies and regional preparation. (https://tirto.id/apa-itunew-normal-dan-bagaimana-penerapannya-saatpandemi-corona-fCSg)

The following is a complete new normal guide from the Ministry of Health:

(https://www.satukanal.com/definisi-new-normal-danpanduan-nya-lengkapnya-dari-kemenkes/)

During the Large-Scale Social Guidelines (PSBB) for the Workplace/Scholl/Colleges:

a. Management Policies in Prevention of Covid-19 Transmission

1) Management should always monitor and update the development of information about COVID19 in its area. (Periodically can be accessed at https://infemerging.kemkes.go.id. And local government policies).

2) Formation of a Covid-19 Handling Team in the workplace consisting of the Management, the personnel section, the K3 section and Health officers, which is strengthened by a Decree from the Head of the Workplace.

3) Leaders or employers provide policies and procedures for workers to report any suspected cases of Covid-19 (symptoms of fever or cough / runny nose / sore throat / shortness of breath) for monitoring by health workers.

4) Not treating positive cases as a stigma.

5)Work from home arrangements.Determine essential workers who need to continue working / coming to work and workers who can do work from home.

\subsection{Blended Learning}

Thorn (2003) explains that blended learning is a combination of face-to-face learning and online learning. This pattern can be described as follows:

\section{Picture 1 Blended Learning}

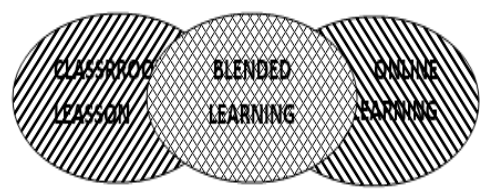

Source: Thorne 2003

Blended learning describes an effort that integrates technological innovation and advantages in online learning with the interaction and participation of faceto-face learning benefits (Thorn: 2003)

Meanwhile, according to [4], blended learning is learning that combines synchronous and asynchronous learning settings appropriately in order to achieve learning objectives. The caracteristics as stated by [4] can be illustrated in the following picture:

Picture 2. Blended Learning Characteristics

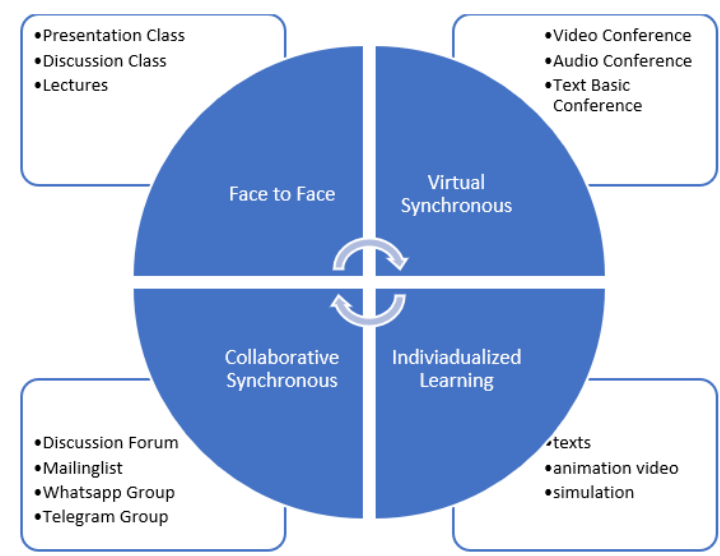

Source: Chaeruman, 2011

Blended Learning should comprise five elements, namely: (1) face-to-face learning, 
independent/individualized learning, (3) application, (4) tutorial, (5) evaluation [5].

\section{5. e-Learning Maturity Model (eMM)}

e learning maturity model (eMM) is a model developed by Herdianto, Roni (2012) which is based on the idea of the Capability Maturity Model (CMM) (Paulk et al: 1993). The concept of CMM is that this model is designed to provide good technique in organizational practice. (Marshall and Mitchell: 2003).

Basically, the eMM process is divided into five (5) categories (learning, development, support, evaluation, and organization) [6]. Each process consists of sub processes that are categorized into 5 things (delivery, planning, definition, management, and optimization).

\section{DISCUSSION}

In this section, the discussion on two main problems, e-learning and eMM process, are taken place. The data were gain from lecturers, students, technical support staff from 3 colleges in the administrative area of North Aceh and Lhokseumawe districts. There are: Universitas Malikussaleh, IAIN Lhokseumawe, and State Polytechnic Lhokseumwe.

\section{1. e-Learning}

The three colleges are running the lectures using online learning due to the government regulation concerning Covid-19 pandemic. All three colleges has their own e-learning application. Universitas Malikusaleh provides "Unimal e-learning application". Application of Edlink/TIPD IAIN is used by State Islamic Instutitute of Lhokseumawe IAIN). State Polytechnic of Lhokseumawe is running "E-Learning Politeknik Negeri Lhokseumawe".

The three colleges also applied two kind of elearning, (1) Electronic based learning using information and communication technology like film, video, slides, LCD projector, etc. (2) Internet based learning using internet facility, in other word we call it online learning. However, during Covid-19 pandemic, the colleges are using online learning.

The three e-learning provides textual and virtual learning. Unimal e-learning application has its own virtual application called Big Blue Button. However, the Big Blue Button platform can not be used properly therefor they can use other virtual application like zoom and google meet.

The followings are the students' and lecturers' perception towards the advantages of e-learning application they are using now:
Table 1. Advantages of e-learning

\begin{tabular}{|c|l|c|c|}
\hline \multirow{2}{*}{ No } & \multicolumn{1}{|c|}{ Criterias } & \multicolumn{2}{|c|}{ Percentages } \\
\cline { 3 - 4 } & & Students & Lecturers \\
\hline 1. & $\begin{array}{l}\text { the quality of learning } \\
\text { is improving }\end{array}$ & 80 & 87 \\
\hline 2. & $\begin{array}{l}\text { The culture of learning } \\
\text { from passive to active } \\
\text { is changing }\end{array}$ & 93.3 & 96.7 \\
\hline 3. & $\begin{array}{l}\text { Lecturers and students } \\
\text { can communicate } \\
\text { easily using internet } \\
\text { facility }\end{array}$ & 53.3 & 70 \\
\hline 4. & $\begin{array}{l}\text { Lecturers and students } \\
\text { can use teaching } \\
\text { materials effectively }\end{array}$ & 63.3 & 73.3 \\
\hline 5. & $\begin{array}{l}\text { Students can review } \\
\text { all materials anytime }\end{array}$ & 72 & 93.3 \\
\hline 6. & $\begin{array}{l}\text { Virtual session can be } \\
\text { done effectively }\end{array}$ & 36.7 & 76.7 \\
\hline 7. & $\begin{array}{l}\text { Good Internet } \\
\text { connection helps the e } \\
\text { learning class }\end{array}$ & 100 & 100 \\
\hline
\end{tabular}

From the above table we can see that most of the criteria are measured high except criteria number 3 and 4. From the interview we found that e-learning can not guarantee that the use of the teaching materials is effective. From the students' point of views, the cause was the lack of understanding when reading the materials in Power Point slides without explanation. While from lecturers' point of view, most of them said it was effective enough.

\subsection{Application of eLearning Maturity Model (eMM)}

As mentioned before that the process of eMM are divided into 5 processes, there are process of learning, development, support, evaluation, and organization. The followings are the process of eMM in levelling the performance:

Table 1. eMM Analysis

\begin{tabular}{|c|c|c|c|}
\hline \multirow{2}{*}{$\begin{array}{l}\text { Learning Process: The } \\
\text { process that has direct } \\
\text { connection with pedagogic } \\
\text { aspects }\end{array}$} & \multicolumn{3}{|c|}{ General Perception } \\
\hline & $\mathbf{U M}$ & IAIN & POL \\
\hline \begin{tabular}{l|l}
1. & Mechanism of Lecturer- \\
students connection is
\end{tabular} & A & A & A \\
\hline
\end{tabular}




\begin{tabular}{|c|c|c|c|c|}
\hline & provided for students & & & \\
\hline 2. & $\begin{array}{l}\text { Students are trained to } \\
\text { use e learning }\end{array}$ & A & A & A \\
\hline 3. & $\begin{array}{l}\text { During the process of } \\
\text { learning students } \\
\text { received feedback. }\end{array}$ & A & A & A \\
\hline
\end{tabular}

Development: All processes regarding the establishment and maintenance of e-learning resources

\begin{tabular}{|l|l|l|l|l}
\hline 1. & All elements are & & & \\
physically established & & & \\
well, strong, and & PA & PA & PA \\
fulfilled all & & & \\
requirements & & & \\
\hline
\end{tabular}

Supports: All processes covering support and management of e-learning operation

\begin{tabular}{|c|l|c|c|c|}
\hline 1. & $\begin{array}{l}\text { Technical assistance is } \\
\text { provided for students }\end{array}$ & A & A & A \\
\hline 2. & $\begin{array}{l}\text { e-Library is provided } \\
\text { for students }\end{array}$ & A & NA & PA \\
\hline 3. & $\begin{array}{l}\text { All students questions, } \\
\text { and complaints are well } \\
\text { managed }\end{array}$ & PA & PA & PA \\
\hline 4. & $\begin{array}{l}\text { Personal service is } \\
\text { provided for students }\end{array}$ & NA & NA & NA \\
\hline
\end{tabular}

Evaluation: All processes regarding evaluation and control of quality throughout all process of e-learning

\begin{tabular}{|l|l|l|l|l|}
\hline 1. & $\begin{array}{l}\text { All students get } \\
\text { feedback concerning } \\
\text { the quality and } \\
\text { effectivity of e-learning. }\end{array}$ & NA & NA & NA \\
\hline
\end{tabular}

Organization: All process of planning and management of institution

\begin{tabular}{|c|l|l|l|l|}
\hline 1 & $\begin{array}{l}\text { All administrative } \\
\text { information is provided } \\
\text { for students. }\end{array}$ & NA & NA & NA \\
\hline 2. & $\begin{array}{l}\text { All pedagogic } \\
\text { information about e } \\
\text { learning is provided for } \\
\text { students }\end{array}$ & NA & NA & NA \\
\hline 3. & $\begin{array}{l}\text { Before class starts the } \\
\text { students are provided } \\
\text { with administrative } \\
\text { information }\end{array}$ & NA & NA & NA \\
\hline
\end{tabular}

Notes: FA : Fully Adequate

A : Adequate

PA : Partially Adequate

NA : Not Adequate

NAs : Not Assessed

The key concept of eMM is capability. The capability context in this model is the ability of adri institutions to ensure that e-learning design, development and delivery are in line with the needs of students, staff, and the institution. In addition to the above program, the teenagers are trained to create website of their gampong, e-commerce website, and making video content. Most of the participants were eager and enthusiast to join the series of activities.

\section{CONCLUSION}

eMM is a framework that can be used in educational institutions to assess and measure the performance of elearning, from devices to hardware support and software and technical operator support.

\section{ACKNOWLEDGMENTS}

The author would like to thank Institute of Research and Community Service, Universitas Malikussaleh and Faculty of Social and Political Sciences, Universitas Malikussaleh, for supporting and funding this community service program.

\section{REFERENCES}

[1] Chaeruman, UA.(2013). Jurnal Teknokrat. Merancang Model Blended Learning Model vol. 17. No. 4 Desember 2013. 399-409.

[2] Fink, Steven. (1986). American Management Association.

[3] Gordon, William I. (2017). Communication: Personal and Public. Alfred Pub.

[4] S. Fink, “American Management Association.” 1986.

[5] W. I. Gordon, Communication: Personal and Public. Alfred Pub, 2017.

[6] A. Madjid, "Merancang Model Blended Learning Designing Blended Learning Model," Afkaruna J., vol. 17, no. 4, pp. 399-409, 2013.

[7] U. Chaeruman, "Merancang Model Blended Learning Model," J. Teknokr., vol. 17, no. 4, pp. 399-409, 2013.

[8] S. A. Santoso, "Pemebelajaran Blended Learning Masa Pandemi.” Penerbit Qiiara Media. Pasuruan, Jawa Timur, 2020.

[9] S. Marshall, “eMM Version 2.3 Process Description." Victoria University of Wellington, 2007. 